\title{
Establishment of transgenic fibroblasts for producing recombinant human interferon- $\alpha$ and erythropoietin in bovine milk
}

\author{
EUI-MAN JUNG ${ }^{1}$, BEUM-SOO AN ${ }^{1}$, YU-KYUNG KIM ${ }^{2}$, INHO HWANG ${ }^{1}$, JONG-YUN LEE ${ }^{2}$, \\ TAE-YOUNG SHIN ${ }^{2}$, SANG-HWAN HYUN ${ }^{3}$, WOO-SUK HWANG ${ }^{2}$ and EUI-BAE JEUNG ${ }^{1}$ \\ ${ }^{1}$ Laboratory of Veterinary Biochemistry and Molecular Biology, College of Veterinary Medicine, \\ Chungbuk National University, Cheongju, Chungbuk 361-763; ${ }^{2}$ Sooam Biotech Research Foundation, \\ Seoul 152-904; ${ }^{3}$ Laboratory of Veterinary Embryology and Biotechnology, College of Veterinary Medicine, \\ Chungbuk National University, Cheongju, Chungbuk 361-763, Republic of Korea
}

Received July 18, 2012; Accepted November 7, 2012

DOI: $10.3892 / \mathrm{mmr} .2012 .1182$

\begin{abstract}
Human interferon $\alpha(\mathrm{IFN}-\alpha)$ and erythropoietin (EPO) have been used for a variety of purposes in clinical medicine. Human IFN- $\alpha$ has been used to treat several types of viral infection and cancer, as well as renal anemia, via stimulation of erythrocyte formation in the bone marrow. Transgenic cattle are excellent candidates for pharmaceutical production for humans due to their ability to produce recombinant proteins in milk. The purpose of the present study was to generate bovine transgenic fibroblasts capable of producing recombinant human IFN- $\alpha$ and EPO proteins in transgenic cattle milk. First, we analyzed the promoter activities of various bovine milk protein genes in $\mathrm{HC} 11$ mouse mammary epithelial cells. The bovine milk protein gene promoters were cloned into the Luc gene in a promoterless pGL3-Basic vector. Presence of the $\alpha \mathrm{S} 1$-casein promoter $(-175$ to $+796 \mathrm{nt})$ resulted in an up to 16 -fold increase in luciferase activity compared with that of the promoter-less construct. In addition, the human IFN- $\alpha$ and EPO genes were identified as significantly overexpressed in $\mathrm{HC} 11$ cells compared with the promoter-less construct. Together, the present results demonstrate that the construct with the $\alpha \mathrm{S} 1$-casein promoter may induce secretion of recombinant human IFN- $\alpha$ and EPO into bovine milk. Furthermore, we generated transgenic fibroblasts expressing human IFN- $\alpha$ and EPO cDNA controlled by the $\alpha$ S1-casein promoter and
\end{abstract}

Correspondence to: Professor Eui-Bae Jeung, Laboratory of Veterinary Biochemistry and Molecular Biology, College of Veterinary Medicine, Chungbuk National University, Cheongju, Chungbuk 361-763, Republic of Korea

E-mail: ebjeung@chungbuk.ac.kr

Dr Woo-Suk Hwang, Sooam Biotech Research Foundation, San 43-41 Oryu-dong, Guro-gu, Seoul 152-904, Republic of Korea

E-mail: hwangws@sooam.org

Key words: cow, fibroblast, IFN- $\alpha$, EPO, milk protein gene promoter two screening markers, enhanced green fluorescent protein and neomycin resistance. These transgenic fibroblasts may be a source of somatic cells for generating transgenic cattle that produce recombinant human IFN- $\alpha$ and EPO proteins during lactation.

\section{Introduction}

Interferons are proteins produced by the immune system in response to a viral infection (1-3). These factors are affiliated with a class of glycoproteins known as cytokines and are classified as interferon $\alpha$ (IFN- $\alpha), \beta$ and $\gamma$. IFN- $\alpha$ and $-\beta$ are involved in immune responses against viral infection (4). IFN- $\gamma$ is crucial for immunity against viral and bacterial infections as well as tumor development (5). In the 1980s, IFN- $\alpha$ obtained from human leukocytes was used in human medicine $(6,7)$. This factor mediates anticancer effects either indirectly by regulating anti-inflammatory and anti-angiogenic responses or directly by affecting the proliferation and differentiation of cancer cells. The direct and indirect effects are followed by activation of the JAK-STAT pathway $(8,9)$.

Erythropoietin (EPO) is a glycoprotein hormone that stimulates the proliferation and differentiation of red blood cell precursors in bone marrow (10). EPO is produced in the liver during fetal and prenatal periods; following birth it is synthesized in the kidney (11). Production and activity of this hormone are sensitive to low oxygen levels in the blood. Kidney cells release EPO when oxygen levels in the blood are low. EPO then stimulates bone marrow to produce more red blood cells, thereby increasing the oxygen-carrying capacity of blood (12,13). Human EPO deficiency is the main cause of anemia in patients with chronic kidney failure. Treatment with recombinant hEPO increases the levels of hemoglobin and hematocrit in anemic patients (14-16).

Recombinant protein production using eukaryotic cell culture systems has been widely used in the pharmaceutical industry (17). However, the production of recombinant proteins by transgenic animals is more effective than eukaryotic cell cultures. Additionally, eukaryotic cell cultures established for recombinant protein production may be problematic due to the absence of appropriate mechanisms for 
performing post-translational modification of the exogenous protein.

Milk was previously identified as a reservoir of recombinant proteins produced by transgenic animals $(18,19)$. Knowledge of the promoter regions of the main functional milk protein genes, including casein and whey acidic protein promoters, is essential for generating transgenic animals that express recombinant proteins in mammary glands (20-23). $\alpha \mathrm{S} 1-$, $\alpha \mathrm{S} 2-, \beta-$, - $\kappa$-casein, $\alpha$-lactalbumin and $\beta$-lactoglobulin account for approximately $90 \%$ of all proteins in bovine milk (24). Secretion of milk proteins in the mammary gland is regulated by steroid and peptide hormones, including insulin, prolactin (PRL) and hydrocortisone (25-27). Promoters of the casein gene possess binding sites for transcription factors, including activators of transcription 5, CCAAT/enhancer binding protein and the glucocorticoid receptor (28-30). Expression of milk protein genes is regulated by interactions between particular hormone-activated transcription factors during mammary gland development.

Previously, production of recombinant proteins in the mammary glands of transgenic animals has been widely reported (18,31-33). In the present study, we established bovine transgenic fibroblasts able to secrete human IFN- $\alpha$ and EPO into milk. These cells are valuable as a sufficient source for somatic cell nuclear transfer methods for generation of transgenic cattle.

\section{Materials and methods}

Animal care. The cattle were fed a standard commercial cow diet (Suwon Purina, Suwon, Kyunggi-Do, Korea) and given water ad libitum in accordance with the animal study guidelines of the SooAm Biotech Research Foundation for Accreditation for Laboratory Animal Care.

Cell culture. Mouse mammalian epithelial HC11 cells (ATCC, Manassas, VA, USA) were cultured in RPMI-1640 medium (Gibco, Carlsbad, CA, USA) containing 10\% fetal bovine serum (FBS), $50 \mathrm{U} / \mathrm{ml}$ penicillin, $50 \mu \mathrm{g} / \mathrm{ml}$ streptomycin (all obtained from Welgene, Daejeon, South Korea), $5 \mu \mathrm{g} / \mathrm{ml}$ insulin (Gibco) and $10 \mathrm{ng} / \mathrm{ml}$ epidermal growth factor (Invitrogen, Carlsbad, CA, USA). Bovine fibroblasts were obtained from a miniature bovine fetus (Deutsche Schwarzbunte) on day 30 of pregnancy. Bovine fibroblasts were then cultured in DMEM (Gibco) containing 10\% FBS, $50 \mathrm{U} / \mathrm{ml}$ penicillin and $50 \mu \mathrm{g} / \mathrm{ml}$ streptomycin. All cells were grown at $37^{\circ} \mathrm{C}$ in a humidified $5 \%$ $\mathrm{CO}_{2}$ atmosphere.

Genomic DNA extraction and PCR. Genomic DNA of the bovine fibroblasts was isolated with a G-DEX ${ }^{\mathrm{TM}}$ IIc Genomic DNA Extraction kit (Intron Biotechnology, Seoul, South Korea). Genomic DNA $(1 \mu \mathrm{g})$ was amplified in a $20-\mu 1$ PCR containing 1 unit LA-Taq polymerase (Takara, Otsu, Shiga, Japan) for long-range PCR or 1 unit i-star Taq polymerase (Intron) for the standard PCR, $2 \mathrm{mM}$ dNTPs (Takara) and 10 pmol of each specific primer. Details of all primers used are presented in Table I. PCR was performed with the following program: denaturation at $95^{\circ} \mathrm{C}$ for $30 \mathrm{sec}$, annealing at $62^{\circ} \mathrm{C}$ for $30 \mathrm{sec}$ and extension at $72^{\circ} \mathrm{C}$ for 1,2 or $3 \mathrm{~min}$. The PCR products were separated on a $0.7 \%$ agarose gel, stained with ethidium bromide and images were captured under UV illumination. Images were scanned using Gel Doc EQ (Bio-Rad Laboratories, Inc., Hercules, CA, USA). The products were then used for cloning.

RNA preparation and RT-PCR. Total RNA from HC11 cells was extracted using TRIzol reagent (Invitrogen) according to the the manufacturer's instructions. Concentration of total RNA was determined by measuring absorbance at $260 \mathrm{~nm}$. First-strand cDNA was prepared by reverse transcription with totalRNA $(1 \mu \mathrm{g})$ using mMLV reverse transcriptase(Invitrogen) and random primers (9-mers; Takara). To determine the optimal conditions for logarithmic phase PCR amplification of the target cDNA, aliquots of total cDNA $(1 \mu \mathrm{g})$ were amplified using various cycle numbers. Mouse cytochrome $\mathrm{c}$ oxidase subunit 1 (1A) gene was used as an internal control to eliminate the possibility of RNA degradation and to control for variations in mRNA concentration. A linear correlation between PCR product band visibility and the number of amplification cycles was observed for the target mRNA sequences. $1 \mathrm{~A}$ and the target human IFN- $\alpha$ or EPO genes were quantified using 28 and 30 cycles, respectively. PCR was performed as follows: denaturation at $95^{\circ} \mathrm{C}$ for $30 \mathrm{sec}$, annealing at $58^{\circ} \mathrm{C}$ for $30 \mathrm{sec}$ and extension at $72^{\circ} \mathrm{C}$ for $30 \mathrm{sec}$. The PCR products were separated in a $2.3 \%$ agarose gel, stained with ethidium bromide and an image was captured under UV illumination. The image was scanned and band density was analyzed using Gel Doc EQ (Bio-Rad Laboratories, Inc.).

Vector construction. Restriction and ligase enzymes were obtained from Takara. Various regions of the milk protein gene promoter were prepared by long-range PCR using bovine genomic DNA of the bovine fibroblasts as a template and specific primers containing restriction enzyme sites (MluI at the $5^{\prime}$ end or XhoI at the $3^{\prime}$ end). Amplified fragments were digested with $M l u \mathrm{I}$ and $X h o \mathrm{I}$ and ligated into the promoter-less luciferase expression plasmid pGL3-Basic (Promega, Madison, WI, USA). The human IFN- $\alpha$ or EPO expression cassette plasmid was produced in several steps. Human IFN- $\alpha$ or EPO cDNA was prepared by PCR using cDNA amplified from total human RNA (Clontech, Mountain View, CA, USA) as a template. Amplified fragments were ligated into the recombinant pGL3 construct containing the milk protein gene promoter. For cassette selection, the enhanced green fluorescent protein (EGFP) gene was amplified from pIRES2-EGFP (Clontech), digested with EcoRV and BamHI and inserted into the pIRES-Neo plasmid (Clontech). The EGFP and neomycin resistance $\left(\mathrm{Neo}^{\mathrm{r}}\right)$ genes were amplified by PCR, digested with SalI and ligated into the recombinant pGL3 vector encoding human IFN- $\alpha$ or EPO controlled by the milk protein gene promoter. Sequences of the targeting vector were confirmed by nucleotide sequencing (Genotech Co. Ltd., Daejeon, South Korea).

Transient transfection and reporter gene assay. Transient transfection was performed using Lipofectamine ${ }^{\mathrm{TM}} 2000$ (Invitrogen) according to the manufacturer's instructions. To normalize transfection efficiencies of the luciferase constructs, the Rous sarcoma virus (RSV)-lacZ plasmid was used to co-transfect the HC11 cells $(34,35)$. Briefly, $3 \times 10^{5}$ cells were 
Table I. Sequences of the primers with specific restriction enzyme sites used in the present study.

\begin{tabular}{|c|c|c|c|}
\hline Name & $\begin{array}{l}\text { Restriction } \\
\text { enzyme }\end{array}$ & Direction & Sequence $\left(5^{\prime}\right.$ to $\left.3^{\prime}\right)$ \\
\hline$\alpha \mathrm{S} 1$-casein promoter $(-2,239)$ & $M l u \mathrm{I}$ & $\mathrm{F}$ & ACG CGT GGC CTT CTT AAA TGA ACA ATG CAA \\
\hline$\alpha \mathrm{S} 1$-casein promoter $(-1,160)$ & $M l u \mathrm{I}$ & $\mathrm{F}$ & ACG CGT AGT GGA CAG CCT GAA CAG TTT TGA \\
\hline$\alpha \mathrm{S} 1$-casein promoter $(-175)$ & $M l u \mathrm{I}$ & $\mathrm{F}$ & ACG CGT AGA ACA ATG CCA TTC CAT TTC CTG \\
\hline$\alpha \mathrm{S} 1$-casein promoter $(+796)$ & XhoI & $\mathrm{R}$ & CTC GAG TGT GCT GGA AAA ATG CGT TTC AGA \\
\hline$\alpha \mathrm{S} 2$-casein promoter $(-257)$ & MluI & $\mathrm{F}$ & ACG CGT GTG GAA GAG CTG AGC TAC ACA AAC \\
\hline$\alpha \mathrm{S} 2$-casein promoter $(+1.296)$ & XhoI & $\mathrm{R}$ & CTC GAG AAG GGG AAG AAT TGG CAG GTG AAA \\
\hline$\beta$-casein promoter $(-331)$ & MluI & $\mathrm{F}$ & ACG CGT CCA AGA TCT CAA AGA CCC ACC GAA \\
\hline$\beta$-casein promoter $(+1,091)$ & XhoI & $\mathrm{R}$ & CTC GAG CAG GGT GTC AGA TCT CTG CCC AGT \\
\hline$\kappa$-casein promoter(-180) & $M l u \mathrm{I}$ & $\mathrm{F}$ & ACG CGT TTT CCT CCT CTG CAT TCC ATT AAC C \\
\hline$\kappa$-casein promoter $(+1,241)$ & XhoI & $\mathrm{R}$ & CTC GAG AGA GCG CAC ACC AGA CTC AAC TCA \\
\hline$\alpha$-lactalbumin (-665) & MluI & $\mathrm{F}$ & ACG CGT AGT GGT ATT GGT GGT TGG GGA TGG \\
\hline$\alpha$-lactalbumin $(+408)$ & XhoI & $\mathrm{R}$ & CTC GAG CCG AAA AAG GCT CTC CAA CCA ATC \\
\hline$\beta$-lactoglobulin (-682) & MluI & $\mathrm{F}$ & ACG CGT GAG GTG GGA GGT TGG GTC CTG TAG \\
\hline$\beta$-lactoglobulin $(+303)$ & XhoI & $\mathrm{R}$ & CTC GAG CCA GCC TCC AGA ATG CAA GAC ACT \\
\hline hIFN- $\alpha$ & NcoI & $\mathrm{F}$ & CCA TGG ATG GCC TTG ACC TTT CGT TTA C \\
\hline hIFN- $\alpha$ & $X b a \mathbf{I}$ & $\mathrm{R}$ & TCT AGA TCA TTC CTT ACT TCT TAA ACT TTC TTG \\
\hline hEPO & NcoI & $\mathrm{F}$ & CCA TGG ATG GGG GTG CAC GAA T \\
\hline hEPO & $X b a \mathbf{I}$ & $\mathrm{R}$ & TCT AGA TCA TCT GTC CCC TGT CCT GCA GG \\
\hline EGFP cDNA & EcoRV & $\mathrm{F}$ & GAT ATC CAC AAC CAT GGT GAG CAA GGG CGA \\
\hline EGFP cDNA & BamHI & $\mathrm{R}$ & GGA TCC TTA CTT GTA CAG CTC GTC CAT GCC \\
\hline hIFN- $\alpha$ confirming primer a & & $\mathrm{F}$ & TAT CTC AGA GCT ATA GGT GA \\
\hline hIFN- $\alpha$ confirming primer $b$ & & $\mathrm{R}$ & AGG GTC TCA TCC CAA GCA \\
\hline hEPO confirming primer $\mathrm{c}$ & & $\mathrm{F}$ & CCC AGT CTT GGG TTC AAG GTA T \\
\hline hEPO confirming primer $d$ & & $\mathrm{R}$ & CAG TGT TCA GCA CAG CCC GT \\
\hline Confirming primer e & & $\mathrm{F}$ & CAT GAA GCA GCA CGA CTT CT \\
\hline Confirming primer $\mathrm{f}$ & & $\mathrm{R}$ & CCT AGG AAT GCT CGT CAA GA \\
\hline Mouse 1A & & $\mathrm{F}$ & CCA GGA TTT GGA ATT ATT TC \\
\hline Mouse 1A & & $\mathrm{R}$ & GAA AAT AAA GCC TAA GGC TC \\
\hline hIFN- $\alpha$ & & $\mathrm{F}$ & TCC AAA AGG CTG AAA CCA TC \\
\hline hIFN- $\alpha$ & & $\mathrm{R}$ & CAG GCA CAA GGG CTG TAT TT \\
\hline hEPO & & $\mathrm{F}$ & CAA GGA GGC CGA GAA TAT CA \\
\hline hEPO & & $\mathrm{R}$ & CAC TGA CGG CTT TAT CCA CA \\
\hline
\end{tabular}

hEPO, human erythropoietin; hIFN- $\alpha$, human interferon $\alpha$; EGFP, enhanced green fluorescent protein; F, forward; R, reverse.

seeded in 6-well tissue culture plates (Corning Incorporated, Corning, NY, USA) 1 day prior to transfection. Constructs $(4 \mu \mathrm{g})$ containing the milk protein gene promoter and $0.5 \mu \mathrm{g}$ of the RSV-lacZ plasmid were used to co-transfect the cells in serum-free DMEM (Gibco). Following incubation for $4 \mathrm{~h}$, the medium was replaced with DMEM containing $10 \%$ FBS, $5 \mu \mathrm{g} / \mathrm{ml}$ PRL (Sigma-Aldrich, St. Louis, MO, USA) and $0.1 \mu \mathrm{M}$ dexamethasone (DEX; Sigma-Aldrich) and the cells were incubated for an additional $48 \mathrm{~h}$. Luciferase activity in the cell lysates was assayed using a Luciferase Assay System. Luminescence was measured with a GloMax 20/20 Luminometer. $\beta$-galactosidase activity was measured using a $\beta$-galactosidase Enzyme Assay System (all purchased from Promega). The relative luciferase activity was calculated as luciferase activity/ $\beta$-galactosidase activity (\%).
Establishment of transgenic cell lines. Bovine fibroblasts were transfected with the linearized construct using Lipofectamine 2000. After $24 \mathrm{~h}$, the transfection medium was replaced with DMEM supplemented with 10\% FBS and $500 \mu \mathrm{g} / \mathrm{ml} \mathrm{G}-418$ (Roche, Indianapolis, IN, USA) for 4 weeks. Antibiotic-resistant colonies were selected according to EGFP expression observed with a fluorescence microscope (Nikon, Tokyo, Japan). The selected colonies were subjected to PCR-based genotyping, using the confirming primer sets presented in Table I.

Data analysis. Data are presented as the mean \pm standard error of the mean (SEM) and were analyzed with Student's t-test and two-pair comparisons. $\mathrm{P}<0.05$ was considered to indicate a statistically significant difference. 


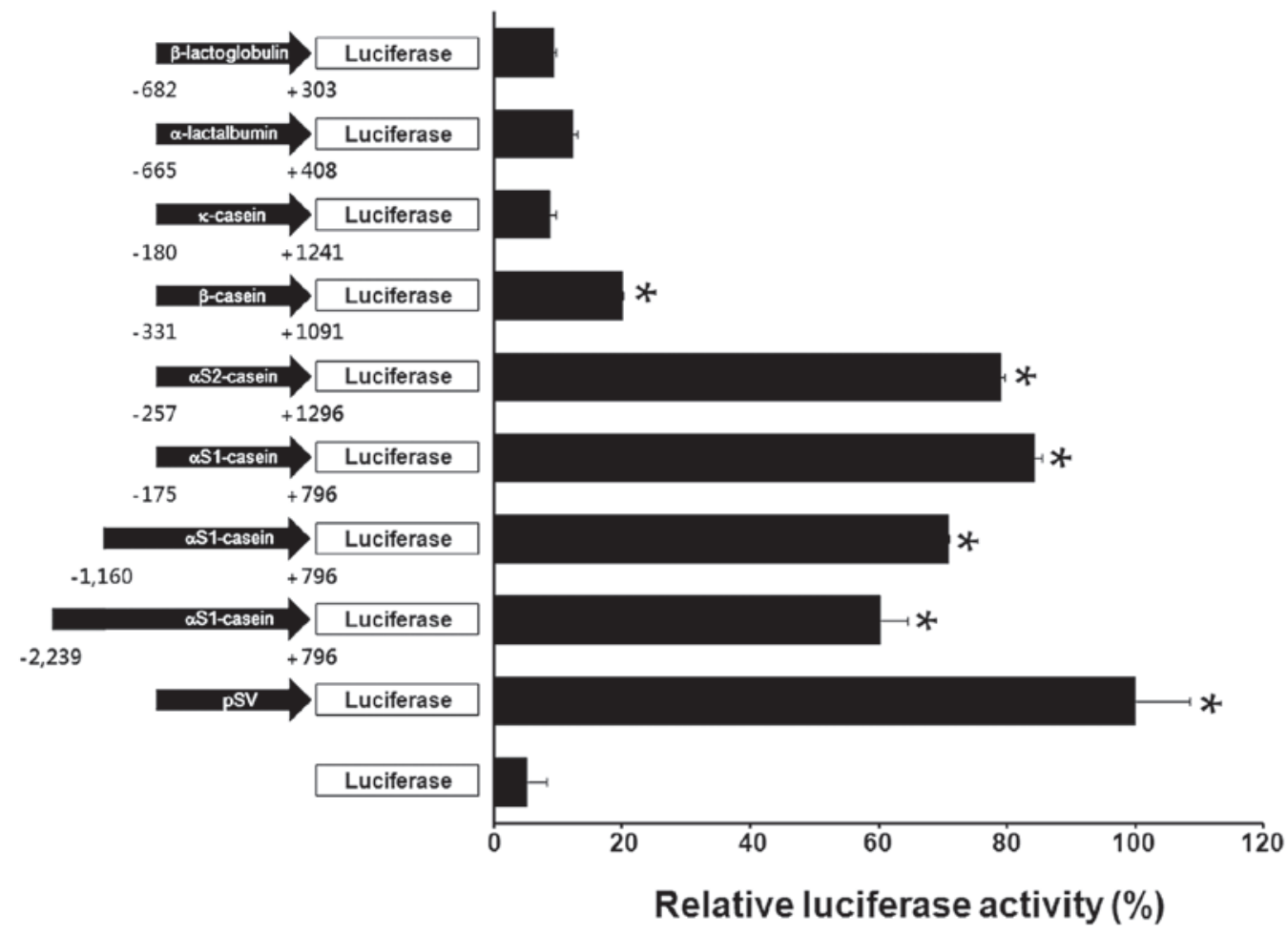

Figure 1. Luciferase reporter gene assay of milk gene promoters following transient transfection. HC11 cells were transiently transfected with the designated constructs and treated with $5 \mu \mathrm{g} / \mathrm{ml}$ PRL and $0.1 \mu \mathrm{M}$ DEX. Cells were co-transfected with a RSV-lacZ expression vector to normalize transfection efficiency. RLU was calculated as the percentage of simian virus 40 promoter (pSV plasmid) set at $100 \%$. Data are expressed as the mean \pm SEM of three independent experiments conducted in triplicate. " $\mathrm{P}<0.05$, vs. RLU of the promoter-less plasmid. DEX, dexamethasone; PRL, prolactin; RLU, relative luciferase units.

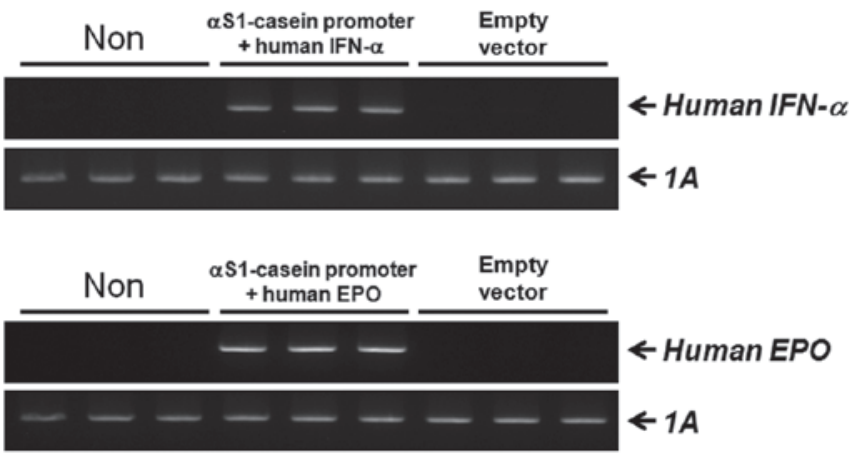

Figure 2. Overexpression of recombinant human IFN- $\alpha$ and EPO in HC11 cells. $\mathrm{HC} 11$ cells were transfected with the human IFN- $\alpha$ and EPO constructs controlled by the $\alpha \mathrm{S} 1$-casein promoter. Cells were then treated with $5 \mu \mathrm{g} / \mathrm{ml}$ PRL and $0.1 \mu \mathrm{M}$ DEX. Human IFN- $\alpha$ and EPO mRNA expression was measured with RT-PCR. IFN- $\alpha$, interferon $\alpha$; EPO, erythropoietin; DEX, dexamethasone; PRL, prolactin.

\section{Results}

Activities of milk protein gene promoters in the HCll cells. We monitored the expression of the reporter luciferase (Luc) gene controlled by bovine milk protein gene promoters in mouse mammary epithelial HC11 cells. Various bovine milk protein gene promoters were linked to the Luc gene in a promoter-less pGL3-Basic vector. These constructs were used to transfect HC11 cells and the relative promoter activities were measured with a Luc reporter gene assay. A previous study demonstrated that the expression of milk protein is increased by DEX with PRL in HC11 cells (36). Therefore, we measured bovine milk protein gene promoter activity in the HC11 cells following treatment with DEX and PRL. As demonstrated in Fig. 1, the $\alpha \mathrm{S} 1$-casein promoter $(-175$ to $+796 \mathrm{nt})$ resulted in a 16 -fold increase of luciferase activity compared with that of the promoter-less construct. However, activities of the $\kappa$-casein, $\alpha$-lactalbumin and $\beta$-lactoglobulin promoters were not identified as significantly altered in the HC11 cells following treatment with DEX and PRL. These results indicate that the $\alpha \mathrm{S} 1$-casein promoter is an ideal candidate for inducing the secretion of recombinant human IFN- $\alpha$ and EPO into bovine milk.

Overexpression of recombinant human IFN- $\alpha$ and EPO in HCll cells. We isolated human IFN- $\alpha$ and EPO cDNA sequences which were sub-cloned into the $\alpha \mathrm{S} 1$-casein promoter. RT-PCR was used to measure the levels of human IFN- $\alpha$ and EPO mRNA produced by our recombinant system in HC11 cells. The expression of human IFN- $\alpha$ and EPO mRNA was evaluated following transient transfection with the two recombinant constructs. As demonstrated in Fig. 2, levels of the transcripts were identified as significantly increased in the transfected HC11 cells. These results demonstrate that the $\alpha \mathrm{S} 1$-casein promoter is suitable for the production of recombinant human IFN- $\alpha$ and EPO in bovine milk.

Establishment of transgenic bovine fibroblast cell lines. The constructs in the present study were used to express human IFN- $\alpha$ and EPO under the control of the $\alpha$ S1-casein promoter, with two selection markers, EGFP and $\mathrm{Neo}^{\mathrm{r}}$ (Fig. 3A and D). These constructs were linearized and used to transfect bovine 
Table II. Transfection efficiency of the recombinant human IFN- $\alpha$ and EPO constructs in bovine fibroblasts.

\begin{tabular}{lcccc}
\hline Cell lines & Transfection trials & G418-resistant colonies & EGFP-positive colonies & PCR-positive colonies \\
\hline Recombinant hIFN- $\alpha$ & 12 & 51 & 49 & 49 \\
Recombinant hEPO & 24 & 62 & 58 & 58 \\
\hline
\end{tabular}

hIFN- $\alpha$, human interferon alpha; hEPO, human erythropoietin.
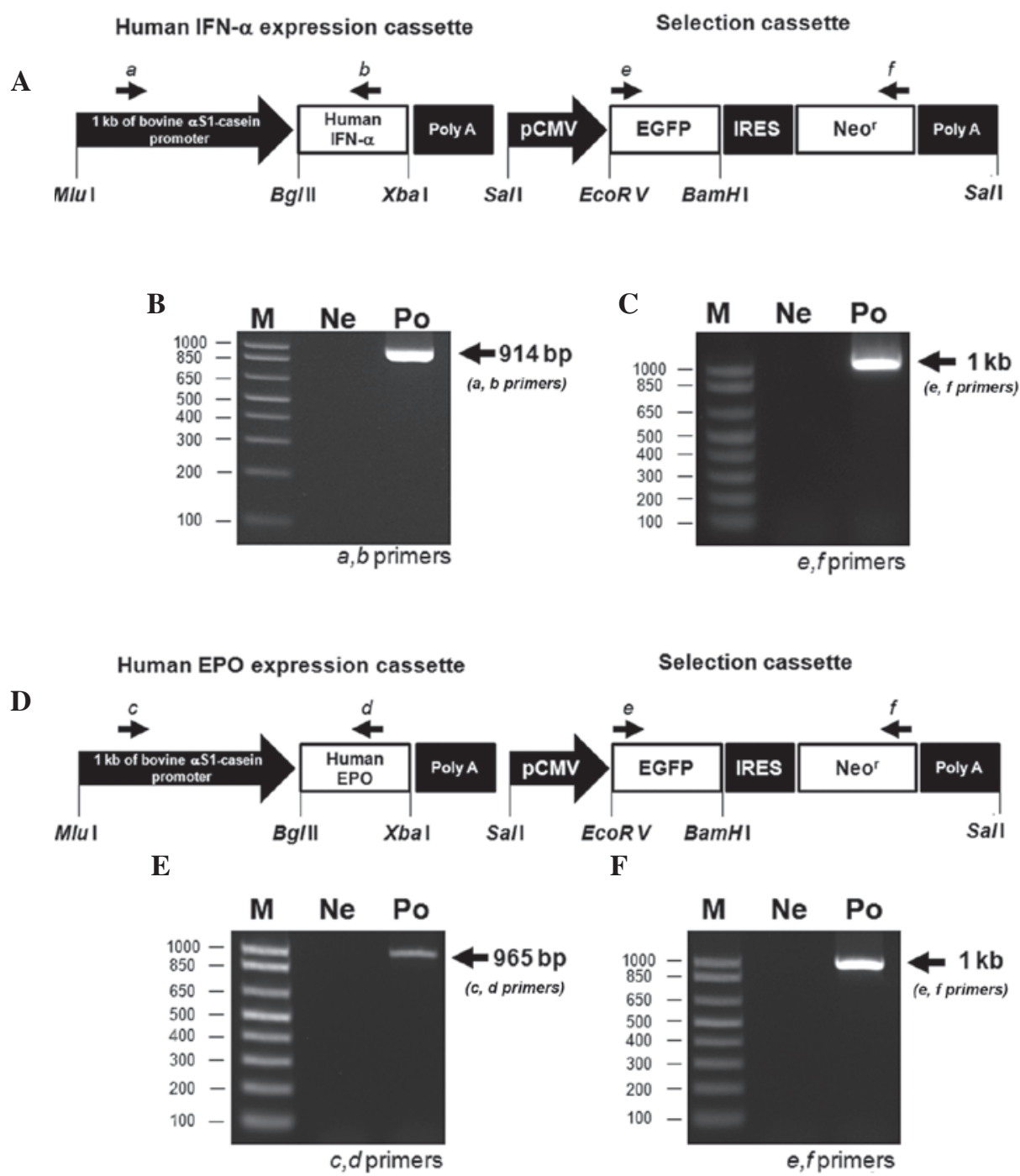

Selection cassette

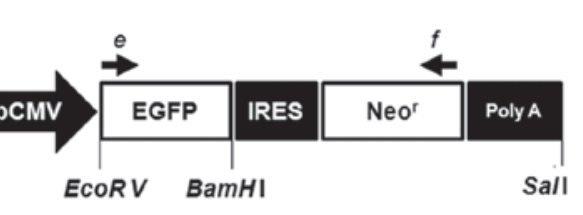

F

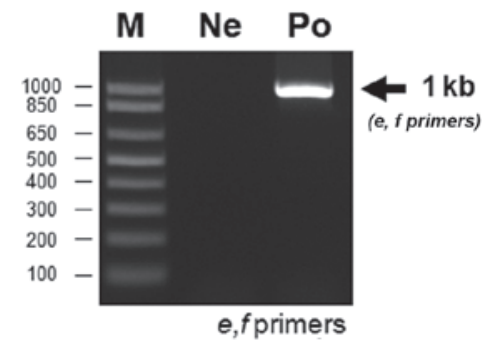

Figure 3. Schematic representation of the two constructs and PCR-based confirmation of the transgenic fibroblast identity. (A and D) Two constructs were used for human IFN- $\alpha$ and EPO expression and contained selection cassettes. The human IFN- $\alpha$ and EPO expression cassettes included the human IFN- $\alpha$ and EPO genes controlled by the $\alpha$ S1-casein promoter. The selection cassette contained EGFP and $\mathrm{Neo}^{\mathrm{r}}$ genes linked by IRES sequences. Integration of the constructs into the fibroblast genomic DNA was confirmed by RT-PCR with specific primers as indicated with arrows. (B and E) Chromosomal insertion of the human IFN- $\alpha$ and EPO expression cassettes was confirmed by PCR. (C and F) Transgenic fibroblasts containing the selection cassette were identified with PCR using specific primers. M, molecular marker; Ne, negative control without template; Po, a positively selected colony expressing both EGFP and Neo ${ }^{\mathrm{r}}$ selection markers; IFN- $\alpha$, interferon $\alpha$; EPO, erythropoietin; EGFP, enhanced green fluorescent protein; $\mathrm{Neo}^{\mathrm{r}}$, neomycin resistance IRES, internal ribosomal entry site.

fibroblasts using a liposomal-mediated gene delivery system. The fibroblasts were incubated in medium containing G-418 for 4 weeks to select for stable transfectants. Following this, expression of the constructs in the clones was confirmed by EGFP expression observed with fluorescent microscopy (Fig. 4). In addition, the clones were identified by PCR-based methods using primers specific for the constructs. Genomic DNA from clones expressing human IFN- $\alpha$ was analyzed with a, b primers (amplicon size, 914 bp; Fig. 3B) or with e, f primers (amplicon size, $1 \mathrm{~kb}$; Fig. 3C). Additionally, genomic DNA from clones expressing human EPO was evaluated with c, d primers (amplicon size, 965 bp; Fig. 3E) or with e, f primers 

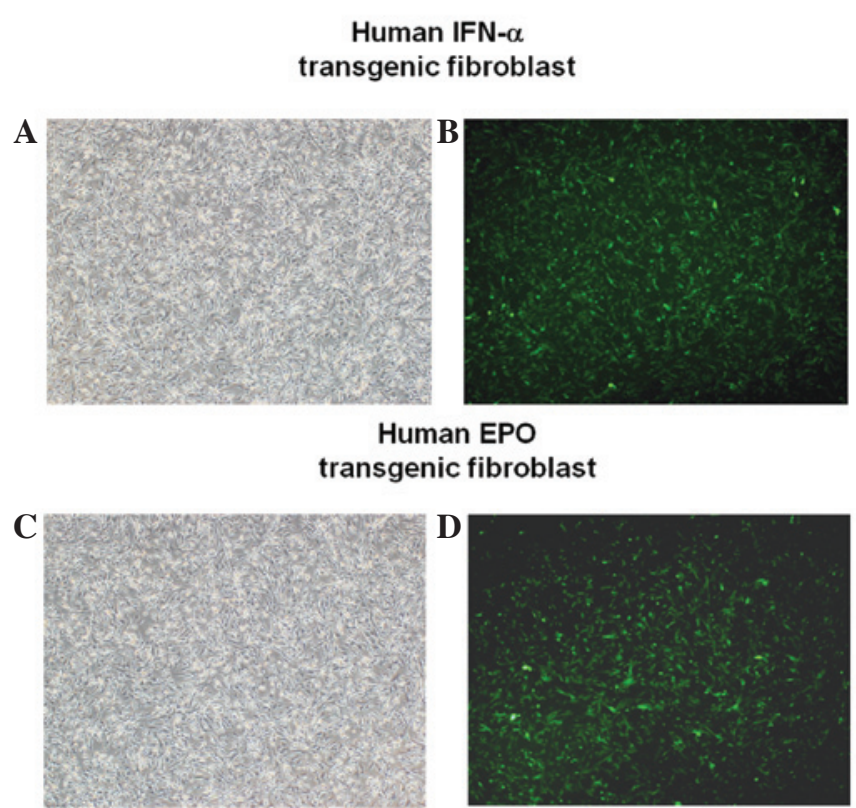

Figure 4. Morphology of the transgenic fibroblasts. Fetal bovine fibroblast were transfected with the constructs using a liposomal-mediated gene delivery system and incubated with G418 for 4 weeks. Fibroblasts stably expressing human (A and B) IFN- $\alpha$ and (C and D) EPO were successfully produced. (A and C) G418-resistant cells were examined under light microscopy. (B and D) EGFP expression was observed with fluorescent microscopy at $\mathrm{x} 40$ magnification. IFN- $\alpha$, interferon $\alpha$; EPO, erythropoietin; EGFP, enhanced green fluorescent protein.

(amplicon size, $1 \mathrm{~kb}$; Fig. 3F). We verified that the transfection efficiency was $\sim 90 \%$ (Table II). Since our constructs included EGFP and $\mathrm{Neo}^{\mathrm{r}}$ selection markers, positive recombination of our target genes into the bovine fibroblast genome was successfully monitored.

\section{Discussion}

In the present study, we generated a bovine fibroblast cell line stably expressing human IFN- $\alpha$ and EPO. These cells expressed the human IFN- $\alpha$ and EPO genes under the control of the bovine $\alpha \mathrm{S} 1$-casein promoter. EGFP and $\mathrm{Neo}^{\mathrm{r}}$ genes, two selection markers, were also included in the constructs to screen for and isolate the transgenic fibroblasts. EGFP expression is an effective visual marker for confirming the identity of transgenic cattle following somatic cell nuclear transfer (SCNT). To select transgenic fibroblasts by antibiotic screening, we used the $\mathrm{Neo}^{\mathrm{r}}$ gene to modify the genome of somatic cells, required for further SCNT-mediated cloning (37,38). Transgenic cattle are the best candidates for producing pharmaceuticals for humans. Transgenic cattle are suitable for the production of large quantities of recombinant proteins in their milk, a trait associated with important economic advantages. Furthermore, expression of recombinant proteins contained in the milk is controlled in a tissue-specific manner $(39,40)$.

We assessed the promoter activities of various bovine milk protein genes in $\mathrm{HC} 11$ cells. The $\alpha \mathrm{S} 1$-casein promoter demonstrated the highest activity level among all the tested promoters. $\alpha \mathrm{S} 1$-casein is a major protein in milk and the promoter has been used to generate transgenic animals (41). Expression of bovine $\alpha \mathrm{S} 1$-casein is regulated by the poly- morphic activator protein-1 binding site (42). Additionally, levels of milk protein and protein yield are associated with various single-strand conformation polymorphism and gene expression patterns (43). PRL stimulates the production of milk by mammary glands. In general, casein gene expression is activated by PRL in mammals $(27,44)$ and expression of $\alpha \mathrm{S} 1$-casein is also induced by PRL in rabbit mammary glands (45). Serum concentrations of PRL are increased during pregnancy, resulting in milk production $(46,47)$. Since our recombinant human IFN- $\alpha$ and EPO constructs contained the $\alpha$ S1-casein promoter, IFN- $\alpha$ and EPO proteins may be synthesized in transgenic cattle during lactation stimulated by PRL.

Human IFN- $\alpha$ has been used to treat several types of viral infection and cancer. This factor induces the immune system response and inhibits cancer cell growth by regulating the expression of several immune-related genes $(48,49)$. Human EPO stimulates the formation of erythrocytes in bone marrow and is used to treat renal anemia (50). Recombinant DNA technology has been used to produce human IFN- $\alpha$ and EPO in eukaryotic cell culture systems $(51,52)$. However, these cellbased systems produce only a limited amount of recombinant proteins. Furthermore, isolating recombinant proteins from these systems is problematic due to an absence of protein post-translational modification. Therefore, we suggest that generating transgenic cattle is the best method for economically producing relatively large quantities of recombinant proteins. Transgenic cattle have an extensive potential for use in biomedicine, agriculture, human health and environmental sustainability $(53,54)$.

In the present study, we established a bovine fibroblast cell line that may be a useful cell source for SCNT procedures to generate transgenic cattle. These transgenic cattle may produce recombinant human IFN- $\alpha$ and EPO proteins in milk. Collectively, these results indicate that this transgenic animal is a good model for producing valuable recombinant human proteins. Additional studies are required to generate transgenic cattle using SCNT technology with transgenic fibroblasts.

\section{Acknowledgements}

The present study was supported by a grant from the Next-Generation BioGreen 21 Program (no. PJ008323), Rural Development Administration, Republic of Korea.

\section{References}

1. Fleischmann WR Jr, Kleyn KM and Baron S: Potentiation of antitumor effect of virus-induced interferon by mouse immune interferon preparations. J Natl Cancer Inst 65: 963-966, 1980.

2. Randall RE and Goodbourn S: Interferons and viruses: an interplay between induction, signalling, antiviral responses and virus countermeasures. J Gen Virol 89: 1-47, 2008.

3. Baron S, Hernandez J, Bekisz J, et al: Clinical model: interferons activate human monocytes to an eradicative tumor cell level in vitro. J Interferon Cytokine Res 27: 157-163, 2007.

4. Liu YJ: IPC: professional type 1 interferon-producing cells and plasmacytoid dendritic cell precursors. Annu Rev Immunol 23: 275-306, 2005.

5. Schoenborn JR and Wilson CB: Regulation of interferon-gamma during innate and adaptive immune responses. Adv Immunol 96: 41-101, 2007.

6. Cantell K and Hirvonen S: Large-scale production of human leukocyte interferon containing 10(8) units per ml. J Gen Virol 39: 541-543, 1978. 
7. Cantell $\mathrm{K}$ and Hirvonen S: Preparation of human leukocyte interferon for clinical use. Tex Rep Biol Med 35: 138-144, 1977.

8. Radaeva S, Jaruga B, Hong F, et al: Interferon-alpha activates multiple STAT signals and down-regulates c-Met in primary human hepatocytes. Gastroenterology 122: 1020-1034, 2002.

9. Wang CJ, Xiao CW, You TG, et al: Interferon-alpha enhances antitumor activities of oncolytic adenovirus-mediated IL-24 expression in hepatocellular carcinoma. Mol Cancer 11: 31, 2012.

10. Jelkmann W: Erythropoietin: structure, control of production and function. Physiol Rev 72: 449-489, 1992.

11. Lacombe C, Da Silva JL, Bruneval P, et al: Identification of tissues and cells producing erythropoietin in the anemic mouse. Contrib Nephrol 66: 17-24, 1988.

12. Neumann E: Regulation of erythropoiesis. Acta Med Austriaca Suppl 6: 360-363, 1979 (In German).

13. Argenti M: Hematosis and erythropoiesis in guinea pigs exposed to low oxygen pressure. Riv Med Aeronaut 14: 283-313, 1951 (In Italian).

14. Radtke HW, Claussner A, Erbes PM, Scheuermann EH, Schoeppe W and Koch KM: Serum erythropoietin concentration in chronic renal failure: relationship to degree of anemia and excretory renal function. Blood 54: 877-884, 1979.

15. Fisher JW: Mechanism of the anemia of chronic renal failure. Nephron 25: 106-111, 1980

16. McGonigle RJ, Wallin JD, Shadduck RK and Fisher JW: Erythropoietin deficiency and inhibition of erythropoiesis in renal insufficiency. Kidney Int 25: 437-444, 1984.

17. Baneyx F: Recombinant protein expression in Escherichia coli. Curr Opin Biotechnol 10: 411-421, 1999.

18. Houdebine LM: Transgenic animal bioreactors. Transgenic Res 9: 305-320, 2000.

19. Lubo $\mathrm{H}$ and Palmer C: Transgenic animal bioreactors - where we are. Transgenic Res 9: 301-304, 2000.

20. Bühler TA, Bruyère T, Went DF, Stranzinger G and Burki K Rabbit beta-casein promoter directs secretion of human interleukin-2 into the milk of transgenic rabbits. Biotechnology (NY) 8: $140-143,1990$

21. Cerdan MG, Young JI, Zino E, et al: Accurate spatial and temporal transgene expression driven by a 3.8-kilobase promoter of the bovine beta-casein gene in the lactating mouse mammary gland. Mol Reprod Dev 49: 236-245, 1998.

22. Ebert KM, DiTullio P, Barry CA, et al: Induction of human tissue plasminogen activator in the mammary gland of transgenic goats. Biotechnology (NY) 12: 699-702, 1994.

23. Gordon K, Lee E, Vitale JA, Smith AE, Westphal H and Hennighausen L: Production of human tissue plasminogen activator in transgenic mouse milk. 1987. Biotechnology 24 : 425-428, 1992

24. Ikonen T, Ojala M and Ruottinen O: Associations between milk protein polymorphism and first lactation milk production traits in Finnish Ayrshire cows. J Dairy Sci 82: 1026-1033, 1999.

25. Hennighausen LG, Sippel AE, Hobbs AA and Rosen JM: Comparative sequence analysis of the mRNAs coding for mouse and rat whey protein. Nucleic Acids Res 10: 3733-3744, 1982

26. Malewski T and Zwierzchowski L: Computer-aided analysis of potential transcription-factor binding sites in the rabbit betacasein gene promoter. Biosystems 36: 109-119, 1995.

27. Rosen JM, Wyszomierski SL and Hadsell D: Regulation of milk protein gene expression. Annu Rev Nutr 19: 407-436, 1999.

28. Raught B, Liao WS and Rosen JM: Developmentally and hormonally regulated CCAAT/enhancer-binding protein isoforms influence beta-casein gene expression. Mol Endocrinol 9: $1223-1232,1995$

29. Buser AC, Gass-HandelEK, Wyszomierski SL, et al: Progesterone receptor repression of prolactin/signal transducer and activator of transcription 5-mediated transcription of the beta-casein gene in mammary epithelial cells. Mol Endocrinol 21: 106-125, 2007.

30. Doppler W, Windegger M, Soratroi C, et al: Expression leveldependent contribution of glucocorticoid receptor domains for functional interaction with STAT5. Mol Cell Biol 21: 3266-3279, 2001.

31. Zinovieva N, Lassnig C, Schams D, et al: Stable production of human insulin-like growth factor 1 (IGF-1) in the milk of hemiand homozygous transgenic rabbits over several generations. Transgenic Res 7: 437-447, 1998

32. Coulibaly S, Besenfelder U, Fleischmann M, et al: Human nerve growth factor beta (hNGF-beta): mammary gland specific expression and production in transgenic rabbits. FEBS Lett 444 111-116, 1999.
33. Devinoy E, Thépot D, Stinnakre MG, et al: High level production of human growth hormone in the milk of transgenic mice: the upstream region of the rabbit whey acidic protein (WAP) gene targets transgene expression to the mammary gland. Transgenic Res 3: 79-89, 1994.

34. Cheng CK, Hoo RL, Chow BK and Leung PC: Functional cooperation between multiple regulatory elements in the untranslated exon 1 stimulates the basal transcription of the human GnRH-II gene. Mol Endocrinol 17: 1175-1191, 2003.

35. Lee GS, Choi KC, Han HJ and Jeung EB: The classical and a non-classical pathways associated with NF-kappaB are involved in estrogen-mediated regulation of calbindin-D9k gene in rat pituitary cells. Mol Cell Endocrinol 277: 42-50, 2007.

36. Song $\mathrm{S}$ and Oka T: Regulation of type II deiodinase expression by EGF and glucocorticoid in HC11 mouse mammary epithelium. Am J Physiol Endocrinol Metab 284: E1119-E1124, 2003.

37. Jung EM, Kim YK, Lee GS, Hyun SH, Hwang WS and Jeung EB: Establishment of inducible cAMP early repressor transgenic fibroblasts in a porcine model of human type 1 diabetes mellitus. Mol Med Report 6: 239-245, 2012

38. Kim YK, Lee GS, Jung EM, Hyun SH, Hwang WS and Jeung EB: Generation of fibroblasts overexpressing liver-specific PEPCK in a miniature pig model of human type 2 diabetes mellitus. Mol Med Report 6: 45-50, 2012.

39. Houdebine LM: Production of pharmaceutical proteins by transgenic animals. Comp Immunol Microbiol Infect Dis 32: 107-121, 2009.

40. Hodges CA and Stice SL: Generation of bovine transgenics using somatic cell nuclear transfer. Reprod Biol Endocrinol 1: 81, 2003.

41. Riego E, Limonta J, Aguilar A, et al: Production of transgenic mice and rabbits that carry and express the human tissue plasminogen activator cDNA under the control of a bovine alpha S1 casein promoter. Theriogenology 39: 1173-1185, 1993.

42. Kuss AW, Gogol J, Bartenschlager $H$ and Geldermann $H$ : Polymorphic AP-1 binding site in bovine CSN1S1 shows quantitative differences in protein binding associated with milk protein expression. J Dairy Sci 88: 2246-2252, 2005.

43. Chessa S, Chiatti F, Ceriotti G, et al: Development of a single nucleotide polymorphism genotyping microarray platform for the identification of bovine milk protein genetic polymorphisms. J Dairy Sci 90: 451-464, 2007.

44. Houdebine LM, Teyssot B, Djiane J and Devinoy E: Control of the expression of milk protein genes by prolactin, glucocorticoids and progesterone. Ann Endocrinol (Paris) 43: 354-369, 1982 (In French).

45. Pierre S, Jolivet G, Devinoy E, et al: A distal region enhances the prolactin induced promoter activity of the rabbit alpha s1-casein gene. Mol Cell Endocrinol 87: 147-156, 1992.

46. Shingo T, Gregg C, Enwere E, et al: Pregnancy-stimulated neurogenesis in the adult female forebrain mediated by prolactin. Science 299: 117-120, 2003

47. Kamel MA, Neulen J, Sayed GH, Salem HT and Breckwoldt M: Heterogeneity of human prolactin levels in serum during the early postpartum period. Gynecol Endocrinol 7: 173-177, 1993.

48. Orru MG, Baita A, Sitzia R, et al: Interferon-alpha-induced psychiatric side effects in patients with chronic viral hepatitis: a prospective, observational, controlled study. Epidemiol Psichiatr Soc 14: 145-153, 2005 (In Italian).

49. Ferrantini M, Capone I and Belardelli F: Interferon-alpha and cancer: mechanisms of action and new perspectives of clinical use. Biochimie 89: 884-893, 2007.

50. Oster W, Herrmann F, Gamm H, et al: Erythropoietin for the treatment of anemia of malignancy associated with neoplastic bone marrow infiltration. J Clin Oncol 8: 956-962, 1990.

51. Son YD, Jeong YT, Park SY and Kim JH: Enhanced sialylation of recombinant human erythropoietin in Chinese hamster ovary cells by combinatorial engineering of selected genes. Glycobiology 21: 1019-1028, 2011.

52. Tuite MF, Dobson MJ, Roberts NA, et al: Regulated high efficiency expression of human interferon-alpha in Saccharomyces cerevisiae. EMBO J 1: 603-608, 1982.

53. Wall RJ, Kerr DE and Bondioli KR: Transgenic dairy cattle: genetic engineering on a large scale. J Dairy Sci 80: 2213-2224, 1997.

54. Zuelke KA: Transgenic modification of cows milk for valueadded processing. Reprod Fertil Dev 10: 671-676, 1998. 